\title{
Antalya ve Eğirdir orman fidanlıklarında bazı yabancı ot mücadele yöntemlerinin fidan gelișimi ve fidanlık maliyetlerine etkileri
}

\section{Effects of some weed control methods on seedling growth and nursery costs at Antalya} and Eğirdir forest nurseries

\author{
Ali KAVGACI ${ }^{1}$ \\ Ersin YILMAZ ${ }^{1}$ \\ Ufuk COŞGUN² \\ Serpil ERKAN ${ }^{1}$ \\ Abdurrahman ÇOBANOĞLU ${ }^{1}$ \\ Selma COŞGUN ${ }^{3}$ (iD \\ Melihat TERZI' ${ }^{4}$ \\ Alime Küçük DIVRİK ${ }^{5}$ \\ Ayşe YAZLIK ${ }^{6}$ \\ ${ }^{1}$ Batı Akdeniz Ormancılık Araștırma \\ Enstitüsü, ANTALYA \\ ${ }^{2}$ Karabük Üniversitesi, Orman Fakültesi, \\ Orman Mühendisliği Bölümü, KARABÜK \\ ${ }^{3}$ Barış mah. Şehirkent sitesi, A Blok, 2/A, \\ Safranbolu, KARABÜK \\ ${ }^{4}$ Antalya Orman Bölge Müdürlüğü, ANTALYA \\ ${ }^{5}$ Isparta Orman Bölge Müdürlüğü, ISPARTA \\ ${ }^{6}$ Düzce Üniversitesi, Ziraat ve Doğa Bilim- \\ leri Fakültesi, DÜZCE
}

Sorumlu yazar (Corresponding author) Ali KAVGACI

alikavgaci1977@yahoo.com

Geliş tarihi (Received)

07.01.2019

Kabul Tarihi (Accepted)

30.04.2019

Atıf (To cite this article): KAVGACI, A, YIL MAZ, E, COSGUN, U, ERKAN, S , COBANOĞLU, A , COŞGUN, S, TERZİ, M , KÜÇÜK DIVRIK, A , YAZLIK, A . (2019). Antalya ve Eğirdir orman fidanlıklarında bazı yabancı o kontrol yöntemlerinin fidan gelisimi ve fidanlık maliyetlerine etkileri. Ormancılık Araştırma Dergisi, 6 (2), 152-166

DOI: https://doi.org/10.17568/ogmoad.509232

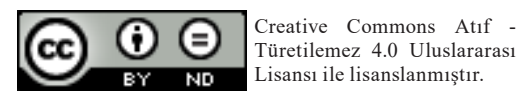

Öz

$\mathrm{Bu}$ çalışma ile Toros sediri (Cedrus libani A. Rich.) ve kızılçam (Pinus brutia Ten.) fidan üretim alanlarında sorun olan yabancı otlar ile mücadelede herbisit ve solarizasyon uygulamalarının fidan gelişimlerine, fidan yaşama oranlarına ve fidanlık maliyetlerine etkileri belirlenmiştir. Araştırma Eğirdir ve Antalya Orman Fidanlıklarında gerçekleştirilmiştir. Çalışmalarda üç farklı etken maddeye sahip herbisitler ve solarizasyon uygulamaları yer almıştır. Uygulamaların maliyet analizleri aynı fidanlıklarda uygulanan mekanik mücadele yöntemi ile karşılaştırılarak yapılmıştır. Herbisit uygulamaları sonucunda yabancı otlarda kontrol sağlanmış olsa da uygulamaların Toros sediri ve kızılçam fidan gelişimi ve yaşam oranlarını düşürdüğü belirlenmiştir. Solarizasyon uygulaması ise yabancı otların örtme derecesini çok yüksek oranda etkilemezken, fidan gelişimi ve yaşama oranlarında artış tespit edilmiştir. Maliyet analizi sonucunda ise herbisit uygulamalarının fidanlık maliyetlerini azalttığ 1 belirlenmiştir. Çalışma genel olarak değerlendirildiğinde; orman fidanlıklarında yabancı otlardan kaynaklanan yüksek maliyet değerlerinin düşürülmesi için herbisit kullanımının ekonomik olacağı ancak bu aşamada fidan sayısı ve gelişimi üzerindeki olumsuz etkilerinden dolayı bir öneride bulunulamayacağı sonucuna varılmıştır. Bu nedenle fidanlıklarda ruhsatlı herbisitlerin kullanımına yönelik araştırmalara devam edilmesi gereklidir.

Anahtar kelimeler: Fidanlık, herbisit, mücadele, maliyet, solarizasyon, yabanc1 ot.

\begin{abstract}
In this work, the effects of herbicides and solarization on weeds at Taurus cedar (Cedrus libani A. Rich.) and Turkish red pine (Pinus brutia Ten.) seedling beds were observed, their effects on seedling emergences and growths were measured and they were assessed in terms of nursery costs. The studies were realized at Eğirdir and Antalya Forest Nurseries. The applications were carried out with three different herbicides including different active substances and solarization. Cost analysis of these applications were done by comparing them with the costs of mechanical treatments. Although herbicides generally affected the occurrence and coverage of weeds, the results were negative in terms of seedling emergences and growths of Taurus cedar and Turkish red pine seedlings. Solarization did not affect the coverage of weeds significantly whereas an increase at seedling emergence and growth was determined. In terms of cost analysis, it was seen that herbicide applications decrease the nursery costs. For a general assessment, to reduce the nursery costs, herbicide applications would be more economic than mechanical applications but at this stage it would not be possible to suggest any herbicide due to their negative effects on seedling survival and growth. At this context, researches with licensed herbicides should be increased to see their positive effects on seedling emergence and growth.
\end{abstract}

Keywords: Nursery, herbicide, management, cost, solarization, weeds. 


\section{Giriş}

Türkiye, 10.000'in üzerinde iletim demetli bitki ve yaklaşık \%30 endemizm ile zengin bir biyolojik çeşitliliğe sahiptir (Güner ve ark., 2012). Bu zenginliğin korunması ve sürdürülebilirliği için en önemli habitatlardan biri olan orman ekosistemlerinin korunması ve süreklilik arz etmesi önemlidir. Türkiye yüz ölçümünün yaklaşık \%28,6's1 (22.342.935 ha) ormanlarla kaplıdır ancak bu alanın büyük bölümü bozuk orman karakterindedir (Anonim, 2015). Bu durum dikkate alındığında orman alanlarının korunması, ormanların sürekliliği ve verimliğinin artırılması için gerekli önlemlerin alınması ve ağaçlandırmaların devamlılığı gereklidir. Ağaçlandırma çalışmalarında kullanılacak fidanlar ise morfolojik ve fizyolojik olarak üstün kaliteli özelliklere sahip olmalıdır (Öztürk ve Deligöz, 2018). Ancak kaliteli fidan üretiminde pek çok unsur önemli rol oynar ve bu unsurları etkileyen en önemli etkenlerden biri de fidan üretim alanlarında karşılaşılan yabancı otlardır (Gökdemir, 1998; Coşgun ve ark., 2002; Öztürk ve Deligöz, 2018).

Tarım ve tarım dışı alanlarda yetişmesi istenilmeyen bitki türleri olarak bilinen yabancı otlar çevrelerindeki diğer bitkiler ile su, 1şık ve besin maddesi yönünden rekabete girerek bitkisel gelişimi etkileyebilmektedirler. Bununla birlikte bu bitkiler hastalık ve zararlılara konukçuluk yaparak ikincil sorunlara neden olabilmekte, bitkisel üretim miktarlarını ciddi oranda azaltabilmekte, işçilik ve üretim maliyetleri bakımından da ciddi ekonomik kayıplara neden olabilmektedir (Gökdemir, 1998; Eşen ve Y1ldız, 2000; Yazlık ve Tepe 2001; Eşen ve ark. 2005; Gündüz ve ark., 2006; Şanlı ve ark., 2009). Örneğin yabancı otların sadece tarım arazilerine verdiği zarar toplamının 125 milyon ton ürün kaybına neden olduğu ve bu kaybın 250 milyon insan için besin kaynağı oluşturabileceği bildirilmiştir (Anonim, 1994).

Yabancı otlar orman fidanlıklarındaki üretim çalışmalarında da problemlere neden olmaktadır (Gökdemir, 1998; Coşgun ve ark., 2002; Öztürk ve Deligöz, 2018). Fidan üretimi yapılan alanlarda yabancı otlar orman ağacı fidanlarına oranla 2-3 kat daha fazla su ve besin maddesi kullanmaktadır (Mathers, 1999). Türkiye'deki orman fidanlıklarında yabancı otlarla mücadele genellikle elle yolma, biçme, toprak işleme ve çapalama gibi kültürel ve mekanik yöntemler şeklinde gerçekleştirildiği ve bu çalışmalardaki işçilik giderlerinin de \%70'e varan oranlarda olduğu bildirilmektedir (Gökdemir, 1998, 2007; Coşgun ve ark., 2002). Ayrıca fidan üretimi yapan küçük işletmelerde harcanan iş gücünün $\% 40$ oranında yabancı otlarla mücadeleye harcandığg (Anonim, 1994) ve kalifiye işçi bulmadaki güçlükler sebebi ile yabancı otlarla mücadelede ilave zorluklar ortaya çıktığı vurgulanmaktadır (Coşgun ve ark., 2002). Bu durumlar dikkate alındığında, fidan üretim çalışmaları için yabancı otlarla mücadelenin ve mücadele yöntemlerinin çeşitliliği konusunda yapılacak çalışmaların gerekliliği ortaya çıkmaktadır.

Yabancı otlarla mücadelede pek çok yöntem (kültürel, fiziksel, mekanik, vb.) olmasına rağmen bu yöntemler arasında hızlı sonuç vermesi ve işçilik maliyetlerinin daha az olması sebebi ile en çok kullanılanı herbisitler (yabancı ot öldürücü ilaçlar) ile uygulanan kimyasal mücadeledir (Delen ve ark., 2005; Parlak, 2016). Herbisitler tarımsal üretim alanlarında, endüstriyel plantasyonlar ve fidanlıklar başta olmak üzere ormancılık uygulamalarında, park-bahçe düzenlemelerinde, yol kenarı bakımları, hava alanı ve tren yolları gibi alanlarda oldukça geniş kullanım alanlarına sahiptir (Cobb ve Reade, 2010; Güncan ve Karaca, 2018). Ancak herbisitlerin yoğun veya hatalı uygulamalarından kaynaklanan çevresel ve sosyoekonomik etkilerinin önüne geçebilmek için bilinçli kullanılması (örneğin etiket bilgilerinin dikkate alınması, ruhsatlı preparatların kullanılması, doğru kalibrasyon vb.) gerekmektedir (Dişbudak, 2008; Kegley ve ark., 2010; Yazlık ve Üremiş, 2017; Güncan ve Karaca, 2018). Öte yandan, kimyasal yapıları ve doğaya verdikleri zararlar nedeniyle doğal alanlarda kullanımları sakıncalı olup bu alanlarda kullanımlarından özenle kaçınmak gerekmektedir (Kegley ve ark., 2010; Boydak ve Çalışkan, 2014).

Yabancı otlarla mücadelede kullanılan bir diğer yöntem de solarizasyon uygulamasıdır (Arslan, 2011). Fiziksel mücadele yöntemleri arasında yer alan bu uygulamada, solarizasyon yapılacak alan toprak doygunluğuna kadar sulanmakta, toprak yüzeyi plastik bir kapama materyali yardımıyla kapatılmakta ve güneşin 1sitıcı etkisinden yararlanılmaktadır (Arslan, 2011). Özellikle tarımsal üretim alanlarında oldukça geniş kullanım alanlarına sahip (Asav ve Kadığlu, 2009; Arslan, 2011) olan bu yöntem sayesinde toprakta oluşan yüksek sıcakl1k, bitkilerle birlikte fungal patojen ve böcekler gibi zararlı diğer etmenlerin ortamdan uzaklaşmasını sağlamaktadır. Herbisitlerin aksine doğal bir mücadele yöntemi olan bu uygulama ile faydalı mikroorganizma faaliyetinin $\operatorname{arttığ} 1$ ve bu etkinin iki yıl devam ettiği, ayrıca solarizasyon sonrası bitkilerin daha iyi gelişerek çiçeklenme sayısının arttığı bildirilmiştir (Katan'a (1988) atfen Moya ve Furukawa, 2000; Arslan, 2011). Ancak Türkiye'de orman fidanlıklarındaki üretim çalışmalarında solarizasyon uygulamasının kullanımına yönelik bir 
çalışmaya rastlanmamıştır.

Yabancı otlar ile mücadelede bahsi geçen yöntemler bulunmasına rağmen Türkiye'de orman fidanlıklarında kültürel ve mekanik mücadeleye ek olarak uygulanabilecek yabancı ot mücadele yöntemleri konusunda bilgiler çok sınırlıdır. Buna ek olarak Türkiye'de orman fidanlıklarında sorun olan çok yıllık yabancı otlara yönelik ruhsatlı herbisit bulunmamaktadır (Güncan ve Karaca, 2018). Ayrıca orman fidanlıklarında herbisit kullanımına yönelik standart ilaçlama deneme metodu da henüz oluşturulmamıştır.

Tüm bu durumları dikkate alarak planlanan çalışma ile Eğirdir Orman Fidanlığında Toros sediri (Cedrus libani A. Rich.) ve Antalya Orman Fidanlığında kızılçam (Pinus brutia Ten.) ekim yastıklarında yabancı otlarla mücadelede; (i) farklı etken maddeli herbisitlerin ve solarizasyon uygulamas1nın fidan gelişimi ve yaşam oranlarına etkisini tespit etmek ve (ii) uygulamaların fidanlık maliyetleri açısından analizini yaparak orman fidanlıklarında yabancı otlarla mücadelede kullanılabilecek/önerilebilecek veriler elde etmek amaçlanmıştır.

\section{Materyal ve Yöntem}

Bu çalışma Batı Akdeniz bölgesinde Isparta Orman Bölge Müdürlüğü, Eğirdir Orman Fidanlık Müdürlüğü çıplak köklü sedir fidanı üretimi yapılan ekim yastıkları ile Antalya Orman Bölge Müdürlüğü, Antalya Orman Fidanlık Müdürlüğü çıplak köklü kızılçam fidanı üretimi yapılan ekim yastıklarında gerçekleştirilmiştir.

Çalışmanın temel materyallerini Toros sediri ve k1zılçam türlerine ait tohumlar, herbisitler (Linuron, Metolachlor+Benoxacor ve Halosulfuron-methyl), siyah PVC polietilen örtü ve motorlu sirt pülverizatörü oluşturmuştur. Denemeler $20 \mathrm{~m} \mathrm{x} \mathrm{1,2} \mathrm{m}$ yastıklarda $\left(24 \mathrm{~m}^{2}\right)$ tesadüf parselleri deneme desenine göre üç tekerrürlü olarak kurulmuştur. Ekim yastıklarının hazırlanması, kullanılan tohum miktar1 ve ekimin yapılmasında her iki fidanlıkta uygulanan rutin uygulama takip edilmiştir.

Herbisit denemelerinde her bir herbisitin üç farklı dozu kullanılmıştır. Buna göre dozlar herbisit etiketlerinde önerilen doz (1 doz), önerilen dozun yar1S1 (0,5 doz) ve önerilen dozun bir buçuk katı olacak şekilde belirlenmiştir. Denemelerde ayrıca herbisit uygulaması yapılmayan yastıklar da yer almış ve bu parseller kontrol olarak değerlendirilmiştir. Herbisitler Toros sediri ve kızılçam ekim yastıklarına; ekim öncesi (Metolachlor+Benoxacor-MetBen), ekim sonrası (Linuron, Metolachlor+Benoxacor ve Halosulfuron-methyl-HalMet) ve çıkış sonrası (yabancı otlar 2-4 yaprak - Linuron ve Halosulfuron-methyl) olmak üzere üç dönemde uygulanmıştır. Herbisit uygulamaları her bir herbisit için belirtilen dönemlerde (ekim öncesi, ekim sonrası ve çıkış sonrası) bir kez yapılmıştır.

Yabancı ot tohumlarının yüksek sicaklık uygulamasıyla (güneş enerjisi) kontrolünün sağlanması amaciyla ele alınan solarizasyon uygulamasinda ise ekim yastıkları ekim öncesinde, yastıkların dinlenmeye bırakıldığı dönemde, toprak doygunluğuna kadar sulanmış, siyah PVC malzemeyle kaplanmış ve yastıklar belirli aralıklarla açılarak sulanmıştır. Bu uygulama sadece Antalya Orman Fidanlığında gerçekleştirilmiştir.

Değerlendirmelerde yabancı otların örtme derecelerini belirlemek amaciyla her parselde beş adet olacak şekilde $\left.1 \mathrm{~m} \mathrm{x} \mathrm{1,2} \mathrm{m} \mathrm{(1,2} \mathrm{m}^{2}\right)$ büyüklüğünde örnek alan alınmış ve bu örnek alanlardaki ölçümler toplam yüz bölümden $(12 \times 10 \mathrm{~cm})$ oluşan bir karelaj yardımıyla yapılmıştır. Bitkilerin örnek alandaki toplam örtme derecesi ve her bir bitkinin örtme derecesi bu karelaj sistemindeki toplam bulunma sayısının yüzde cinsinden ifadesi olarak tespit edilmiştir. Değerlendirmelerde ayrıca her bir uygulamadaki fidanların yaşama yüzdeleri (\%) ve bu fidanların boy (cm) ve kök boğazı çapı (mm) gelişimlerine yönelik ölçümler, fidan sökümlerinden hemen önce yapılmıştır.

Çalışmada maliyetleri ortaya koymak amacıyla her bir uygulama için iş-zaman analizleri hesaplanmıştır. Fidanlıklara göre bitkiler farklılık gösterdiği için mekanik mücadeleye ait iş-zaman analizi her bir fidanlık için ayrı ayrı hesaplanmış, herbisit ve solarizasyona yönelik olarak ise tek bir iş-zaman analizi yapılmıştır.

Herbisit maliyet hesaplarında, kullanılan ekipman, ekipmanın hazırlığ 1 , işçilik uygulama süreleri ve işçilik maliyetleri hesaplanmıştır. Solarizasyon işleminde ise ekim yastığının toprak doygunluğuna kadar sulanması, ardından PVC örtü ile kaplanması, PVC malzeme maliyeti ve alanın tesisinde işçilik süresi ve işçi sayısı değerlendirmeleri gerçekleştirilmiştir. Mekanik mücadele maliyetinde ise hesaplamalar, doğrudan malzeme giderleri ile ücret ve maaş kalemlerinden hareketle yapılmıştır.

Elde edilen verilerin analizi SPSS paket programı (IBM, 2016) kullanılarak gerçekleştirilmiştir. Verilere normallik testi uygulanmış ve normal dağılım göstermeyen verilere dönüşüm (logaritmik) uygulanmıştır. Uygulamalar arasında fark olup olmadığını belirlemek için varyans analizi (Anova testi) yapılmıştır. Fark olması durumunda farklı işlem gruplarını belirleyebilmek için Duncan testi uygulanmıştır. 


\section{Bulgular}

Çalışma kapsamında yapılan yabancı ot tespiti çalışmaları sonucunda Antalya Orman Fidanlığındaki kızılçam ekim yastıklarında 14 familyadan 22 bitki taksonu tespit edilmiştir (Tablo 1). En fazla takson sayısı sirasiyla Asteraceae (\%23), Poaceae (\%18) ve Brassicaceae (\%9) familyalarında bulunurken bitkilerin \%50'si diğer familyalardandır. Yabancı otların yaşam formları incelendiğinde ise $\% 72$ tek y1llık, $\% 18$ çok yıllık, $\% 4$ iki yıllık ve $\% 4$ çok yıllık form- larına sahip oldukları anlaşılmıştır.

Eğirdir Orman Fidanlığı Toros sediri ekim yastıklarında ise 17 familyadan 32 bitki taksonu tespit edilmiştir (Tablo 2). Bu bitkilerin \%13’ü Poaceae familyası bireylerinden oluşurken eşit sayıda takson barındiran Asteraceae, Brassicaceae, Fabaceae ve Polygonaceae familyalarına ait taksonların toplam oran $1 \% 37$ 'dir. Yaşam formları incelendiğinde ise bitkilerin \%75'inin tek y1llık, \%19'unun çok yıllık ve \%6'sının ise geofit olduğu tespit edilmiştir.

Tablo 1. Antalya Orman Fidanlığı kızılçam (Pinus brutia) ekim yastıklarında rastlanılan yabancı otlar Table 1. Weeds on the Turkish red pine (Pinus brutia) sowing beds at Antalya Forest Nursery

\begin{tabular}{|c|c|c|c|c|c|c|c|}
\hline No & Biti adı & Familya & $\begin{array}{l}\text { Yaşam } \\
\text { Formu }\end{array}$ & No & Bitki adı & Familya & $\begin{array}{l}\text { Yaşam } \\
\text { Formu }\end{array}$ \\
\hline 1 & Amaranthus retroflexus & Amaranthaceae & Tek yıllık & 12 & Lamium amplexicaule & Lamiaceae & Tek yıllık \\
\hline 2 & Anthemis pseudocotula & Asteraceae & Tek yıllık & 13 & Mercurialis annua & Euphorbiaceae & Tek yıllık \\
\hline 3 & Calendula arvensis & Asteraceae & Tek yıllık & 14 & Poa annua & Poaceae & Tek yillık \\
\hline 4 & Calystegia sylvatica & Convolvulaceae & Çok y1llık & 15 & Polygonum aviculare & Polygonaceae & Tek y1llık \\
\hline 5 & Capsella bursa-pastoris & Brassicaceae & Tek yıllık & 16 & Portulaca oleracea & Portulacaceae & Tek y1llık \\
\hline 6 & Chenopodium album & Chenopodiaceae & Tek yıllık & 17 & Psoralea bituminosa & Fabaceae & Tek yıllık \\
\hline 7 & Cynodon dactylon & Poaceae & Çok yillık & 18 & Raphanus raphanistrum & Brassicaceae & Tek yillık \\
\hline 8 & Cyperus rotundus & Poaceae & Çok yıllık & 19 & Senecio vulgaris & Asteraceae & Tek yıllık \\
\hline 9 & Fumaria capreolata & Papaveraceae & Tek yıllık & 20 & Sonchus asper & Asteraceae & Tek y1llık \\
\hline 10 & $\begin{array}{l}\text { Heliotropium } \\
\text { hirsutissimum }\end{array}$ & Boraginaceae & Tek yıllık & 21 & $\begin{array}{l}\text { Sorghum halepense var. } \\
\text { halepense }\end{array}$ & Poaceae & Çok yıllık \\
\hline 11 & Lactuca serriola & Asteraceae & İki yıllık & 22 & Veronica sp. & Plantaginaceae & Tek y1llık \\
\hline
\end{tabular}

Tablo 2. Eğirdir Orman Fidanlı̆̆ı Toros sediri (Cedrus libani) ekim yastıklarında rastlanılan yabancı otlar Table 2. Weeds on the Taurus cedar (Cedrus libani) sowing beds at Eğirdir Forest Nursery

\begin{tabular}{|c|c|c|c|c|c|c|c|}
\hline No & Bitki ad 1 & Familya & $\begin{array}{l}\text { Yaşam } \\
\text { Formu }\end{array}$ & No & Bitki ad 1 & Familya & $\begin{array}{l}\text { Yaşam } \\
\text { Formu }\end{array}$ \\
\hline 1 & Anagallis arvensis & Primulaceae & Tek yıllık & 17 & Onobrychis sp. & Fabaceae & Tek yıllık \\
\hline 2 & Capsella bursa-pastoris & Brassicaceae & Tek yıllık & 18 & Onosma sp. & Boraginaceae & Tek yıllık \\
\hline 3 & Cardaria draba & Brassicaceae & Tek yıllık & 19 & Papaver somniferum & Papaveraceae & Tek yıllık \\
\hline 4 & Catapodium rigidum & Poaceae & Tek yıllık & 20 & Plantago lanceolata & Plantaginaceae & Çok yıllık \\
\hline 5 & Chenopodium album & Chenopodiaceae & Tek yıllık & 21 & Poa anпиа & Poaceae & Tek yıllık \\
\hline 6 & Cirsium arvense & Asteraceae & Çok yıllık & 22 & Polygonum lapathifolium & Polygonaceae & Tek yıllık \\
\hline 7 & Convolvulus arvensis & Convolvulaceae & Çok yıllık & 23 & Rumex crispus & Polygonaceae & Çok yıllık \\
\hline 8 & Cyperus rotundus & Poaceae & Çok yıllık & 24 & Rumex tuberosus & Polygonaceae & Geofit \\
\hline 9 & Daucus guttatus & Apiaceae & Tek yıllık & 25 & Scrophularia sp. & Scrophulariaceae & Tek yıllık \\
\hline 10 & Equisetum ramosissimum & Equisetaceae & Çok y1llık & 26 & Senecio vulgaris & Asteraceae & Tek yıllık \\
\hline 11 & Euphorbia helioscopia & Euphorbiaceae & Tek yıllık & 27 & Setaria viridis & Poaceae & Tek yıllık \\
\hline 12 & Fumaria capreolata & Papaveraceae & Tek yıllık & 28 & Sinapis arvensis & Brassicaceae & Tek yillık \\
\hline 13 & $\begin{array}{l}\text { Heliotropium } \\
\text { hirsutissimum }\end{array}$ & Boraginaceae & Tek yıllık & 29 & Sonchus asper & Asteraceae & Tek yıllık \\
\hline 14 & Lamium amplexicaule & Lamiaceae & Tek yıllık & 30 & Trifolium nigrescens & Fabaceae & Tek yıllık \\
\hline 15 & Linaria simplex & Scrophulariaceae & Tek yıllık & 31 & Veronica polita & Plantaginaceae & Tek yıllık \\
\hline 16 & Medicago minima & Fabaceae & Tek yıllık & 32 & Vincetoxicum canescens & Asclepiadaceae & Geofit \\
\hline
\end{tabular}

Antalya ve Eğirdir Orman Fidanlığında kızılçam ve Toros sediri fidan üretim parsellerinde yapılan uygulamalar, uygulamaların iş-zaman analizleri ve maliyet hesaplamalarına ait sonuçlar ayrı başlıklar hâlinde aşağıda sunulmuştur.

\subsection{Antalya Orman Fidanlığı kızılçam (Pinus brutia) fidan üretim alanında herbisit ve solarizasyon uygulamaları}

Herbisit ve solarizasyon uygulamalariyla kontrol parsellerinde bulunduğu tespit edilen bitkilerin 
ortalama örtme dereceleri Tablo 3'te sunulmuştur. Ekim yastıklarında en fazla oranda tespit edilen Cyperus rotundus türü tüm uygulama sahalarında görülürken bu türü sırasıyla Fumaria capreolata, Portulaca oleraceae, Senecio vulgaris, Capsella bursa-pastoris ve Sonchus asper izlemiştir.

Herbisit etken maddelerinin bitkilere farklı etkiler göstermesinin bir sonucu olarak, yabancı otların örtme dereceleri açısından uygulamalar arasında önemli farkların bulunduğu anlaşılmıştır (Tablo 4 - $\mathrm{p} \leq 0,05)$. Benzer şekilde uygulamalar arasında fidan sayıları açısından da istatistiki olarak önemli farklılıklar tespit edilmiştir (Tablo $4-\mathrm{p} \leq$ 0,05). Herbisit uygulamasiyla birlikte fidan sayıs1nın kontrol ve solarizasyon uygulamalarına oranla önemli derecede düştüğü görülmüştür $(p \leq 0,05)$. Bu noktada uygulanan herbisitin dozunun da fidan sayısı üzerinde etkili olduğu, doz artıkça fidan sayısının düştüğü tespit edilmiştir.
Fidan boyu açısından değerlendirme yapıldığında ise uygulamalar arasında istatistiki açıdan önemli farkların bulunduğu görülmüştür (Tablo $4-\mathrm{p} \leq$ $0,05)$. Herbisit uygulamalarına ait değerler genel olarak solarizasyon ve kontrol uygulamalarının gerisinde kalmıştır. Yalnızca ekim sonrası MetBen uygulaması solarisazyon ile aynı grupta yer almıştır. Herbisitlerin uygulanan dozları itibariyle de fidan boyları arasında önemli farkların olduğu, herbisit dozu arttıkça fidan boyunun düştüğü tespit edilmiştir.

Yabancı otla mücadele uygulamalarının fidanların kök boğazı çapı üzerindeki etkisi incelendiğinde de uygulamalar arasında önemli farkların bulunduğu görülmektedir (Tablo 4 - $\mathrm{p} \leq 0,05$ ). Herbisit uygulamaları genel olarak düşük çap gelişimine neden olurken, solarizasyon uygulaması en yüksek çap gelişimin gerçekleştiği uygulama olarak belirginleşmektedir.

Tablo 3. Farklı uygulamalar itibariyle ekim yastıklarındaki bitkiler ve ortalama örtme dereceleri (\%) (Antalya

Orman Fidanlığı, K: Kontrol ES: Ekim sonrası, ÇS: Çıkış Sonrası - Veriler yüzde cinsinden bitkilerin ortalama örtme derecesini vermektedir.)

Table 3. Weeds and their mean covers (\%) on the sowing beds by different application (Antalya Forest Nursery, PS: Post-sowing, PE: Post-emergence- Values represent the mean percentages of plant covers)

\begin{tabular}{|c|c|c|c|c|c|c|c|c|c|c|c|c|c|c|}
\hline \multirow{3}{*}{$\frac{\text { Uygulama }}{\text { Doz }}$} & \multirow{3}{*}{$\mathrm{S}$} & \multirow{3}{*}{$\mathrm{K}$} & \multicolumn{6}{|c|}{ Metolachlor+Benoxacor } & \multirow{2}{*}{\multicolumn{3}{|c|}{$\begin{array}{l}\text { Linuron } \\
\text { ES / PS }\end{array}$}} & \multirow{2}{*}{\multicolumn{3}{|c|}{$\begin{array}{l}\text { Halosulfuron- } \\
\text { methyl ÇS /PE }\end{array}$}} \\
\hline & & & \multicolumn{3}{|c|}{ EÖ - PreS } & \multicolumn{3}{|c|}{ ES / PS } & & & & & & \\
\hline & & & 0,5 & 1 & 1,5 & 0,5 & 1 & 1,5 & 0,5 & 1 & 1,5 & 0,5 & 1 & 1,5 \\
\hline Cyperus rotundus & 8 & 13,4 & 9,2 & 1,8 & 1,5 & 4,1 & 1,4 & 2,7 & 47,7 & 55,9 & 55 & 8,9 & 15 & 24 \\
\hline Fumaria capreolata & 7 & 21,4 & 14,7 & 1,1 & 0,1 & 0,7 & 0 & 0,3 & 6,5 & 5,5 & 2,3 & 7,9 & 7,3 & 20,6 \\
\hline Portulaca oleracea & 52,4 & 57,4 & 27,3 & 6,3 & 2,2 & 3,1 & 0,3 & 0,3 & 0,3 & 0,1 & 0 & 50 & 59 & 70 \\
\hline Senecio vulgaris & 0,2 & 7,4 & 21,7 & 6,8 & 4,9 & 5,3 & 0,8 & 0,4 & 2,5 & 0,1 & 0 & 15,9 & 13,5 & 1,1 \\
\hline Capsella bursa-pastoris & 2,1 & 16,1 & 16,1 & 4,3 & 2,5 & 0,5 & 0,2 & 0 & 0 & 0 & 0 & 2,9 & 8,2 & 6,3 \\
\hline Sonchus asper & 0,2 & 18 & 18,1 & 3,3 & 3,5 & 0 & 0 & 0,4 & 0 & 0,5 & 0,5 & 12 & 9,1 & 4,1 \\
\hline Veronica sp. & 0 & 1 & 0,1 & 0 & 0 & 0 & 0 & 0 & 0 & 0 & 0 & 2,8 & 3,9 & 1,4 \\
\hline $\begin{array}{l}\text { Sorghum halepense var. } \\
\text { halepense }\end{array}$ & 0 & 0 & 1,7 & 10,3 & 15,3 & 16,3 & 2,5 & 0,5 & 0,1 & 0,2 & 0 & 0 & 0 & 0 \\
\hline Raphanus raphanistrum & 0,6 & 4,6 & 6 & 4,3 & 0,1 & 3,8 & 0 & 0,7 & 0 & 0 & 0 & 0 & 0 & 0 \\
\hline Chenopodium album & 0,3 & 0 & 0 & 0 & 0 & 0,1 & 0,1 & 0 & 0 & 0 & 0 & 0,7 & 1,1 & 0,3 \\
\hline Lamium amplexicaule & 0 & 0,1 & 0 & 0,1 & 0,1 & 0 & 0 & 0 & 0,1 & 0 & 0 & 0,6 & 0,7 & 0,9 \\
\hline Cynodon dactylon & 0 & 0,1 & 0,3 & 0 & 0 & 0 & 0,3 & 0,7 & 0 & 0 & 0,3 & 0 & 1,2 & 1,3 \\
\hline Amaranthus retroflexus & 0,3 & 0,7 & 0 & 0 & 0 & 0 & 0 & 0 & 0 & 0 & 0 & 0 & 0 & 0,1 \\
\hline $\begin{array}{l}\text { Heliotropium } \\
\text { hirsutissimum }\end{array}$ & 0 & 0 & 0,3 & 0,1 & 0 & 0 & 0 & 0,1 & 0,3 & 0,1 & 0 & 0 & 0 & 0 \\
\hline Psoralea bituminosa & 1,2 & 0 & 0 & 0 & 0 & 0 & 0 & 0 & 0 & 0 & 0 & 0 & 0 & 0 \\
\hline Mercurialis anпиа & 0 & 0 & 0 & 0 & 0 & 0 & 1,6 & 0 & 0 & 0 & 0 & 0 & 0 & 0 \\
\hline Calendula arvensis & 0 & 0,1 & 0,1 & 0 & 0,3 & 0 & 0,1 & 0,1 & 0 & 0 & 0 & 0 & 0 & 0 \\
\hline Anthemis pseudocotula & 0,1 & 0 & 0 & 0,1 & 0 & 0 & 0 & 0 & 0 & 0 & 0 & 0 & 0 & 0 \\
\hline Poа аппиа & 0 & 0 & 0 & 0 & 0 & 0 & 0 & 0 & 0 & 0 & 0 & 0,5 & 0,1 & 0,1 \\
\hline Polygonum aviculare & 0 & 0 & 0 & 0 & 0 & 0 & 0 & 0 & 0,1 & 0 & 0 & 0,3 & 0 & 0 \\
\hline Calystegia sylvatica & 0,1 & 0 & 0 & 0 & 0 & 0 & 0 & 0 & 0 & 0 & 0 & 0 & 0 & 0 \\
\hline Lactuca serriola & 0 & 0 & 0 & 0 & 0 & 0 & 0 & 0 & 0 & 0 & 0 & 0 & 0 & 0 \\
\hline
\end{tabular}

Kızılçam fidan üretim alanında herbisit ve solarizasyon uygulamaları kapsamında ortaya çıkan sonuçlar şu şekildedir;
Ekim sonrası Metolachlor+Benoxacor uygulamas1nın yabancı otların örtme derecesi üzerinde en etkili uygulama olduğu tespit edilmiştir (yabancı otların örtme oranı: \%14). Ancak bu uygulamanın yapıld1- 
ğ1 yastıklardaki fidan sayıları $\mathrm{m}^{2}$ 'de ortalama 166 olarak elde edilmiştir. Bu değerler kontrol parsellerine oranla (metrede ortalama 309 fidan) önemli derecede düşüktür. Benzer şekilde fidan boyu itibariyle de ekim sonrası Metolachlor+Benoxacor uygulama sahasındaki fidanların boylarının (ortalama $11,04 \mathrm{~cm}$ ) kontrol parsellerindeki fidanlara göre $(13,11 \mathrm{~cm})$ düşük olduğu belirlenmiştir. Ekim sonrası Metolachlor+Benoxacor uygulama sahasındaki fidanların çap gelişimi (ortalama 2,12 mm) ise kontrol parsellerindeki fidanlar ile yakın değerlere $(2,21 \mathrm{~mm})$ sahiptir ve bu değerler arasındaki fark önemsizdir.
Yabancı otlara etkisi bakımından benzer özellikler gösteren ekim öncesi Metolachlor+Benoxacor $(\% 44)$ ve ekim sonrası Linuron (\%57) uygulamalarının 1m'deki fidan sayıları da (sırasıyla 102 ve 92 adet fidan) kontrole ve solarizasyona göre çok düşüktür. Her iki uygulamadaki fidanların boy (sırasıyla ortalama 7,16 ve 9,56 cm) değerleri de kontrole (ortalama 13,11 cm) göre düşüktür. Fidanların çap gelişimi bakımından ise ekim öncesi Metolachlor+Benoxacor uygulaması yapılan sahadaki fidanların çapları $(2,03 \mathrm{~mm})$ kontrole $(2,21$ $\mathrm{mm})$ göre oldukça düşük olsa da ekim sonrası Linuron uygulanan fidanların çap gelişimi $(2,29 \mathrm{~mm})$ daha yüksektir.

Tablo 4. Herbisit ile solarizasyon ve kontrol uygulamalarının fidan sayısı, fidan boyu, kök boğazı çapı ve yabancı otların örtme dereceleri açısından karşılaştırılması (1, 2, 3 ve 4 rakamları Duncan testi sonucunda ortaya çıkan farkl1 grupları temsil etmektedir)

Table 4. Comparison of herbicide, solarisation and control treatments in terms of seedling amount, seedling height, root collar diameter and weed cover (1,2,3 and 4 represent different groups obtained through Duncan test)

\begin{tabular}{|c|c|c|c|c|c|}
\hline \multicolumn{6}{|l|}{ Fidan say1s1 (adet) } \\
\hline Uygulama & $\mathrm{N}$ & 1 & 2 & 3 & 4 \\
\hline Linuron ekim sonras1 & 9 & 92,5556 & & & \\
\hline MetBen ekim öncesi & 9 & 102,0444 & & & \\
\hline Halmet çıkış sonrası & 9 & 116,5111 & & & \\
\hline MetBen ekim sonrası & 9 & & 165,9778 & & \\
\hline Kontrol & 9 & & & 309,4000 & \\
\hline Solarizasyon & 9 & & & & 395,2667 \\
\hline Sig. & &, 166 & 1,000 & 1,000 & 1,000 \\
\hline \multicolumn{6}{|l|}{ Fidan boyu $(\mathrm{cm})$} \\
\hline Uygulama & $\mathrm{N}$ & 1 & 2 & 3 & 4 \\
\hline MetBen ekim öncesi & 9 & 7,1621 & & & \\
\hline HalMet çıkış sonrası & 9 & & 9,1330 & & \\
\hline Linuron ekim sonrası & 9 & & 9,5627 & & \\
\hline MetBen ekim sonras1 & 9 & & & 11,0360 & \\
\hline Solarizasyon & 9 & & & 11,3738 & \\
\hline Kontrol & 9 & & & & 13,1140 \\
\hline Sig. & & 1,000 &, 453 &, 554 & 1,000 \\
\hline \multicolumn{6}{|l|}{ Kök boğazı çapı (mm) } \\
\hline Uygulama & $\mathrm{N}$ & 1 & 2 & 3 & \\
\hline MetBen ekim öncesi & 9 & 2,0272 & & & \\
\hline HalMet çıkış sonrası & 9 & 2,1002 & & & \\
\hline MetBen ekim sonras1 & 9 & 2,1218 & 2,1218 & & \\
\hline Kontrol & 9 & 2,2149 & 2,2149 & & \\
\hline Linuron ekim sonrası & 9 & & 2,2899 & & \\
\hline Solarizasyon & 9 & & & 2,4854 & \\
\hline Sig. & & 052 & 071 & 1,000 & \\
\hline \multicolumn{6}{|c|}{ Yabancı otların örtme dereceleri (Veriye logaritmik transformasyon uygulanmıştır) } \\
\hline Uygulama & $\mathrm{N}$ & 1 & 2 & 3 & 4 \\
\hline Kontrol & 9 & 0,9224 & & & \\
\hline HalMet çıkış sonrası & 9 & 1,1903 & 1,1903 & & \\
\hline Solarizasyon & 9 & & 1,2453 & & \\
\hline Linuron ekim sonras1 & 9 & & & 1,6280 & \\
\hline MetBen ekim öncesi & 9 & & & 1,6620 & 1,6620 \\
\hline MetBen ekim sonrası & 9 & & & & 1,9325 \\
\hline Sig. & &, 067 &, 700 &, 812 &, 064 \\
\hline
\end{tabular}


Çıkış sonrası Halosulfuron-methyl uygulamasının yabancı otların örtme derecesine etkisi ise diğer herbisitlere oranla oldukça düşüktür (yabancı otların örtme oranı: \%79,49). Bu uygulamanın yapıldığ1 yastıklar fidan sayısı itibariyle kontrol parsellerinin oldukça gerisinde kalmıştır (sırasıyla metrede ortalama 116 ve 309 fidan). Bu fidanlar boy ve çap gelişimi açısından değerlendirildiğinde de (sırasıyla ortalama $9,13 \mathrm{~cm}$ ve $2,10 \mathrm{~mm}$ ) kontrol ve solarizasyon parsellerindeki fidanların oldukça gerisinde (s1rasıyla $13,11 \mathrm{~cm}$ ve $2,21 \mathrm{~mm}$ ) kaldığ görülmektedir.

Solarizasyon uygulamasının yabancı otlar üzerindeki etkisi düşük olmuştur (Yabancı otların ortala- ma örtme derecesi: \%78,67). Bu oran her ne kadar çok yüksek olmasa da solarizasyon uygulaması yapılan yastıklardan elde edilen fidan sayıs1 395 adet fidan/m ile en yüksek orana sahiptir. Bu sayı kontrol parsellerindeki fidan sayısından da fazladır ve iki uygulama arasındaki fidan sayısı itibariyle var olan bu fark istatistiki açıdan önemlidir. Solarizasyon uygulamasındaki fidanlar boy gelişimi $(11,37 \mathrm{~cm})$ itibariyle kontrol parsellerindeki boy gelişiminin $(13,11 \mathrm{~cm})$ gerisinde olmakla birlikte, çap gelişimi itibariyle daha iyi gelişim göstermektedirler (sirasiyla 2,48 mm ve 2,21 mm - Tablo 4). Uygulamalar arasında var olan bu fark istatistiki açıdan da önemlidir.

Tablo 5. Farklı uygulamalar itibariyle ekim yastıklarındaki bitkiler ve ortalama örtme dereceleri (\%) (Eğirdir Orman Fidanlığı, K: Kontrol ES: Ekim sonrası, ÇS: Çıkış Sonrası - Veriler yüzde cinsinden bitkilerin ortalama örtme derecesini vermektedir.)

Table 5. Weeds and their mean covers (\%) on the sowing beds by different application (Eğirdir Forest Nursery, PS: Post-sowing, PE: Post-emergence, - Values represent the mean percentages of plant covers)

\begin{tabular}{|c|c|c|c|c|c|c|c|}
\hline \multirow[t]{3}{*}{ Uygulama } & \multirow{2}{*}{\multicolumn{3}{|c|}{ Linuron ES / PS }} & \multicolumn{4}{|c|}{ Linuron ÇS / PE } \\
\hline & & & & \multicolumn{4}{|c|}{ Dozlar } \\
\hline & 0 & 0,5 & 1 & 1,5 & 0,5 & 1 & 1,5 \\
\hline Lamium amplexicaule & 1,3 & 0,9 & 1,1 & 1 & 1,1 & 0,3 & 0,3 \\
\hline Fumaria capreolata & 0,4 & 0,1 & 0,3 & 0,2 & 0,3 & 0,1 & 0,2 \\
\hline Cirsium arvense & 4,7 & 1,3 & 0,3 & 0,1 & 0,2 & 0 & 0,1 \\
\hline Onobrychis sp. & 17,3 & 0,1 & 0,1 & 0 & 0,9 & 0,1 & 0 \\
\hline Polygonum lapathifolium & 0 & 0,3 & 0,1 & 0,6 & 0,8 & 0,1 & 0 \\
\hline Poa annua & 0,4 & 0,1 & 0,2 & 0,2 & 0,2 & 0,3 & 0 \\
\hline Plantago lanceolata & 0,1 & 0,1 & 0 & 0,1 & 0,1 & 0 & 0 \\
\hline Senecio vulgaris & 0,3 & 0,1 & 0 & 0 & 0,1 & 0,3 & 0 \\
\hline Chenopodium album & 0,7 & 0,1 & 0,1 & 0 & 0 & 0 & 0 \\
\hline Sinapis arvensis & 0,9 & 0 & 0 & 0 & 0,3 & 0 & 0 \\
\hline Catapodium rigidum & 0,3 & 0 & 0 & 0,1 & 0,1 & 0 & 0 \\
\hline Papaver somniferum & 0,1 & 0 & 0 & 0 & 0,1 & 0,1 & 0 \\
\hline Veronica polita & 0 & 0,1 & 0 & 0,2 & 0,4 & 0 & 0 \\
\hline Capsella bursa-pastoris & 3,3 & 0 & 0 & 0 & 0 & 0 & 0 \\
\hline Rumex tuberosus & 0 & 0,1 & 0 & 0 & 0,2 & 0 & 0 \\
\hline Linaria simplex & 0 & 0 & 0,1 & 0 & 0,3 & 0,2 & 0 \\
\hline Heliotropium hirsutissimum & 0 & 0 & 0 & 0 & 0 & 0 & 0 \\
\hline Rumex crispus & 0,6 & 0 & 0 & 0 & 0 & 0 & 0 \\
\hline Scrophularia sp. & 9,6 & 0 & 0 & 0 & 0 & 0 & 0 \\
\hline Onosma sp. & 0 & 0,1 & 0 & 0 & 0 & 0 & 0 \\
\hline Vincetoxicum canescens & 0 & 0 & 0,1 & 0 & 0 & 0 & 0 \\
\hline Convolvulus arvensis & 0 & 0 & 0 & 0,1 & 0 & 0 & 0 \\
\hline Setaria viridis & 0 & 0 & 0 & 0 & 0 & 0 & 0 \\
\hline Cardaria draba & 0 & 0 & 0 & 0 & 0 & 0 & 0 \\
\hline Trifolium nigrescens & 0 & 0 & 0 & 0 & 0 & 0 & 0 \\
\hline Medicago minima & 0 & 0 & 0 & 0 & 0 & 0 & 0 \\
\hline Anagallis arvensis & 0,3 & 0 & 0 & 0 & 0 & 0 & 0 \\
\hline Sonchus asper & 0,7 & 0 & 0 & 0 & 0 & 0 & 0 \\
\hline Daucus guttatus & 0,3 & 0 & 0 & 0 & 0 & 0 & 0 \\
\hline Cyperus rotundus & 0,3 & 0 & 0 & 0 & 0 & 0 & 0 \\
\hline Euphorbia helioscopia & 0 & 0 & 0 & 0 & 0,1 & 0 & 0 \\
\hline Equisetum ramosissimum & 0 & 0 & 0 & 0 & 0,1 & 0 & 0 \\
\hline
\end{tabular}




\subsection{Eğirdir Orman Fidanlığı Toros sediri (Cedrus libani) fidan üretim alanında herbisit uygulamaları}

Farklı herbisit uygulamalarına bağlı olarak ekim yastıkları üzerinde bulunan bitkilerin ortalama örtme dereceleri Tablo 5'te sunulmuştur. Farklı uygulamalara göre ekim yastıkları üzerinde en fazla bulunan bitkiler ise sirasiyla Lamium amplexicaule, Fumaria capreolata, Cirsium arvense ve Onobrychis sp. türleri olmuştur.

Eğirdir orman fidanlığındaki ekim öncesi herbisit uygulamalarında, otlarda hemen hemen hiçbir çimlenme yaşanmazken Toros sedirinde de herhangi bir çimlenme gerçekleşmemiştir. Bu nedenle ekim öncesi dönemde kullanılan herbisitin (Metolachlor+Benoxacor) sedir fidanlarında yüksek fitotoksite gösterdiği belirlenmiştir.

Herbisit uygulamalarının ekim yastıkları üzerindeki yabancı otların örtme dereceleri üzerine etkisini ortaya koymak amaciyla yapılan varyans analizine göre uygulamalar arasında önemli farkların bulunduğu tespit edilmiştir (Tablo $6-\mathrm{p} \leq 0,05$ ). Benzer şekilde fidan sayıları açısından da uygulamalar arasında önemli farklar bulunmaktadır (Tablo 6 - $\mathrm{p}$ $\leq 0,05)$. Bu noktada uygulanan herbisitin dozunun da fidan sayısı üzerinde etkili olduğu, doz artıkça fidan sayısının düştüğü tespit edilmiştir.

Çalışma kapsamında yapılan herbisit uygulamalarının fidan boyları üzerindeki etkisi açısından önemli farklarının bulunduğu tespit edilmiştir (Tablo 6 - $\mathrm{p} \leq 0,05$ ). Uygulamalar kök boğazı çapı açısından değerlendirildiğinde de önemli farkların olduğu görülmüştür (Tablo 6 - p $\leq 0,05$ ).

Toros sediri fidan üretim alanında herbisit uygulamaları kapsamında ortaya çıkan sonuçlar şu şekildedir:

Yukarıda da belirtildiği üzere ekim öncesi herbisit uygulaması yabancı otların çimlenmesini etkilemiş fakat Toros sedirine yönelik herhangi bir çimlenme de gerçekleşmemiştir. Ekim sonrası ve çıkış sonrası herbisit uygulamaları da (Linuron), yabanc1 otlara etki bakımından olumlu sonuçlar ortaya koymuşlardır (sırasıyla \%5,29; \%4,56 ) ve kontrol parsellerine $(\% 43,33)$ oranla önemli bir farkl1lık ortaya çıkmıştır (Tablo 6).

Tablo 6. Herbisit uygulamalarının fidan sayısı, fidan boyu, kök boğazı çapı ve yabancı otların örtme dereceleri itibariyle karșılaștırılması.

Table 6. Comparison of herbicide treatments in terms of seedling amount, seedling height, root collar diameter and weed cover (1,2, 3 and 4 represent different groups obtained through Duncan test)

\begin{tabular}{|c|c|c|c|}
\hline Fidan say1s1 (adet) & & & \\
\hline Uygulama & 1 & 2 & 3 \\
\hline Linuron çık1ş sonrası & 168,8444 & & \\
\hline Linuron ekim sonras1 & & 554,2444 & \\
\hline Kontrol & & & 980,9333 \\
\hline Sig. & 1,000 & 1,000 & 1,000 \\
\hline \multicolumn{4}{|l|}{ Fidan boyu $(\mathrm{cm})$} \\
\hline Uygulama & 1 & 2 & \\
\hline Linuron ekim sonras1 & 7,5884 & & \\
\hline Linuron çık1ş sonrası & 8,4952 & & \\
\hline Kontrol & & 10,8447 & \\
\hline Sig. & ,153 & 1,000 & \\
\hline \multicolumn{4}{|l|}{ Kök boğazı çapı (mm) } \\
\hline Uygulama & $\mathrm{N}$ & 1 & 2 \\
\hline Linuron ekim sonras1 & 9 & 2,7242 & \\
\hline Linuron çık1ş sonrası & 9 & 2,8646 & 2,8646 \\
\hline Kontrol & 9 & & 3,1202 \\
\hline Sig. & &, 343 &, 094 \\
\hline Uygulama & 1 & 2 & \\
\hline Linuron çıkış sonrası & 4,5556 & & \\
\hline Linuron ekim sonras1 & 5,2889 & & \\
\hline Kontrol & & 43,3333 & \\
\hline Sig. & ,387 & 1,000 & \\
\hline
\end{tabular}


Kontrol parsellerinde 1 m'lik yastıkta ortalama 981 fidan bulunurken çıkış sonrası herbisit (Linuron) uygulanan sahada bu sayı herbisitin oluşturduğu fitotoksiteler nedeniyle ortalama 169 fidan olmuştur. Ancak ekim sonrası Linuron uygulamas1 yapılan yastıklarda fitotoksite oranı çok daha az olmuş ve 1 m'lik yastıkta ortalama 554 fidan elde edilmiştir. Fidan sayısı itibariyle bu uygulama çıkış sonrası yapılan uygulamaya göre daha etkili olurken kontrol parsellerine oranla etkisi düşük kalmıştır (Tablo 6).

Herbisit uygulamalarının Toros sediri fidanlarının boyları üzerindeki etkisi olumsuz yönde olmuştur. Ekim sonrası ve çıkış sonrası herbisit uygulamalarında (Linuron) fidan boyları sirasıyla $7,59 \mathrm{~cm}$ ve $8,49 \mathrm{~cm}$ olurken bu değer kontrol parsellerinde 10,84 olmuştur ve herbisit uygulamalarıyla kontrol parselleri arasında istatistiki olarak önemli bir fark ortaya çıkmıştır. Benzer şekilde kök boğazı çapı gelişimi açısından da herbisit uygulamalarıyla kontrol parselleri arasında önemli fark bulunurken ve ekim ve çıkış sonrası herbisit uygulamalarında (Linuron) kök boğazı çap1 sırasıyla 2,72 mm ve 2,86 mm olurken kontrol parsellerinde bu değer 3,12 $\mathrm{mm}$ olmuştur. Yani herbisit uygulamaları kök boğazı çapını olumsuz etkilemiştir. Bununla birlikte çıkış sonrası Linuron uygulaması kontrol ile aynı grupta yer almıştır ve istatistiki açıdan aralarındaki fark önemsizdir (Tablo 6).

\subsection{Yabancı otlarla mücadeleye yönelik birim- zaman analizleri}

Herbisit ve yalnızca Antalya Orman Fidanlığında uygulanan solarizasyon uygulamalarının birim zaman analizleri benzer olduğundan fidanlık ayırmaksızın tek bir birim zaman analizi yapılmıştır. Ancak elle ot alma işlemi yabancı otlara göre farkl1lık göstereceğinden ve fidanlıklara göre yabancı otlar da farklılaştığından her bir fidanlık için ayrı birim zaman analizi yapılmıştır.

\subsubsection{Elle ot alma birim zaman analizleri}

Elle ot almada bir dekar alanda iki işçiyle ot alınması için gereken insan çalışma zamanı; i) faaliyet zamanı, ii) dinlenme zamanı payı (\%), iii) dağılım zamanı payı (\%) ve iv) hazırlık zamanı toplamından oluşmaktadır. Faaliyet zamanı, ana faaliyet zamanı ile yan faaliyet zamanının toplamından oluşmaktadır. Çalışma kapsamında 100 $\mathrm{m}^{2}$ alanda iki işçiye elle ot alma işlemi yaptırılmış ve kronometreyle zaman ölçülerek ana faaliyet zamanı elde edilmiştir. Buna göre 1 da alanın elle ot alma ana faaliyet zamanı Eğirdir Orman Fidanlığ 1 için 3.090 dakika ve Antalya Orman Fidanlığı için 2.941 dakika olarak belirlenmiştir. Elle ot alma iş- leminin yan faaliyet zamanı bulunmadığından faaliyet zamanı ana faaliyet zamanına eşittir.

Elle ot alma işlemi kapsamında dikkate alınan dinlenme zamanı, Peter Steele ve Partners adlı kuruluşun karşılaştırmalı zorluk ve puan değiştirme çizelgelerinden yararlanılarak belirlenmiştir (Doğan'a (2015) atfen Erdem ve ark., 2017). Buna göre elle ot alma işlemi kapsamında dikkate alınan dinlenme zamanı payı Tablo 7'de sunulmuştur.

Tablo 7. Elle ot alma, ilaçlama (Pülverizatör) ve solarizasyon işlemlerinde dinlenme payı

Table 7. Resting times for different applications (Weeding by hand, pulverization and solarization)

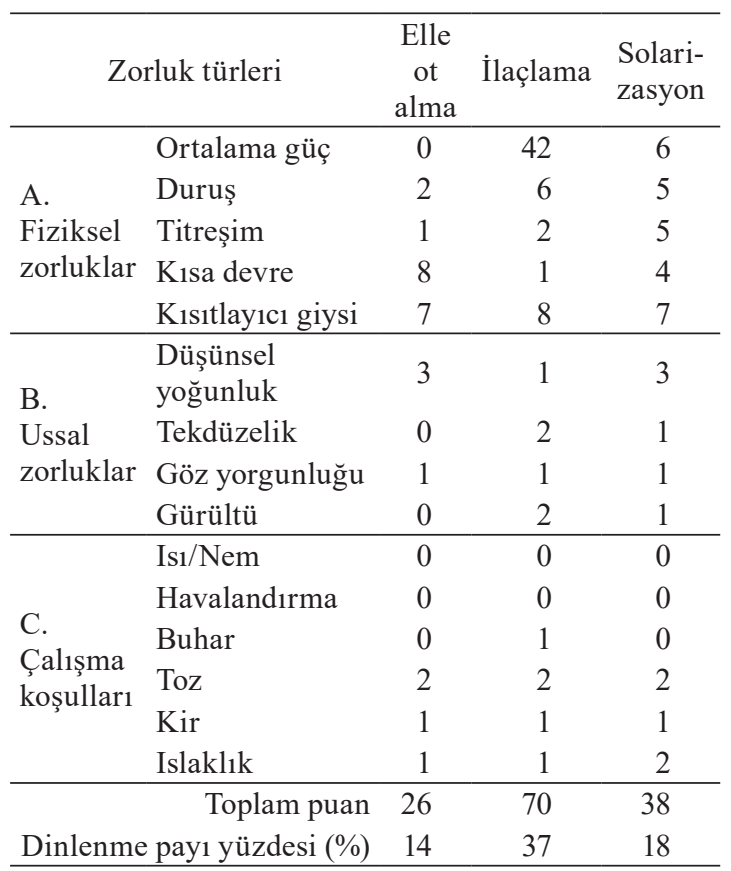

Dağılım zamanı, kişisel ve nesnel dağılım zamanı olarak iki grupta değerlendirilmektedir (Erdem ve ark., 2017). Ancak elle ot alma işleminde nesnel dağılım zamanı ve hazırlık zamanı bulunmamaktadır. Kişisel dağılım zamanı ise su içme ve kişisel ihtiyaç zamanlarından oluşmaktadır (Tablo 8). Sigara kullanım zamanı, iş yerindeki iş güvenliği nedeniyle kişisel dağılım zamanı içinde dikkate alınmamıştır. Çalışma amacına uygun olmayan telefon ve/veya arkadaşla görüşme zamanı ile çay içme zamanı dinlenme zamanı kapsamında değerlendirilmiş olup kişisel dağılım zamanı içinde dikkate alınmamıştır.

Tüm bu bilgiler 1şığında, Eğirdir Orman Fidanlığı için elle ot alma işleminde birim-zaman; 3577,29 dk./da. (=3090 dk./da + [3090 dk./da x (14/100)] + [3090 dk./da x (1,77/100)]) olarak hesaplanmıştır. $\mathrm{Bu}$ değer Antalya Orman Fidanlığı içinse 3404,80 dk./da.'dır (=2941 dk./da + [2941 dk./da x (14/100)] $+[2941 \mathrm{dk} . / \mathrm{da} \times(1,77 / 100)])$. 
Tablo 8. Elle ot alma işleminde dağ 1 lım zamanı Table 8 . Distribution time for weeding by hand

\begin{tabular}{lccc}
\hline $\begin{array}{c}\text { Dağılım } \\
\text { zamanı (gün) } \\
\text { bileşenleri }\end{array}$ & $\begin{array}{c}\text { Sıklık } \\
\text { (adet) }\end{array}$ & $\begin{array}{c}\text { Ort. } \\
\text { Zaman }\end{array}$ & $\begin{array}{c}\text { Toplam } \\
\text { zaman }\end{array}$ \\
\hline $\begin{array}{l}\text { Su İçme zamanı } \\
\text { Kişisel ihtiyaç }\end{array}$ & 5 & $0,5 \mathrm{dk}$ & $2,50 \mathrm{dk}$ \\
zamanı & 3 & $2,0 \mathrm{dk}$ & $6,00 \mathrm{dk}$ \\
$\begin{array}{l}\text { Dağılım zamanı toplamı } \\
\text { Dağılım zamanının, günlük çalışma }\end{array}$ & $\%, 50 \mathrm{dk}$ \\
zamanı (480 dk) içindeki payı & $\% 1,77$ \\
\hline
\end{tabular}

\subsubsection{Herbisit uygulaması birim zamanı analizi}

Herbisit uygulamasında kullanılan pülverizatör aletinin kullanımı işleminde 1 da alanda bir iş̧̧i ile uygulama için gerekli makine çalışma zamanı; (i) faaliyet zamanı, (ii) dinlenme zamanı payı (\%), (iii) dağılım zamanı payı (\%) ve (iv) hazırlık zamanı toplamından oluşmaktadır.

Faaliyet zamanı, ana faaliyet zamanı ile yan faaliyet zamanı toplamından oluşmaktadır. Çalışma kapsamında $100 \mathrm{~m}^{2}$ alanda bir iş̧̧iyle pülverizatörle herbisit uygulaması işlemi yapılmış ve kronometreyle zaman ölçülerek ana faaliyet zamanı elde edilmiştir. Buna göre 1 da alanın pülverizatörle herbisit uygulaması ana faaliyet zamanı 48,33 dakika olarak belirlenmiştir. Pülverizatörle herbisit uygulaması işleminin yan faaliyet zamanı bulunmadığından faaliyet zamanı ana faaliyet zamanına eşittir.

Pülverizatörle herbisit uygulaması işlemi kapsamında dikkate alınacak dinlenme zamanı payı Tablo 7'de verilmiştir. Pülverizatörün dolu ağırlı̆̆ 1 $26 \mathrm{~kg}$ (57 libre) olarak alınmış olup düşük yeğinlikte (bir gücün ya da bir etkinliğin gittikçe yükselme ya da alçalma durumlarından her biri, derecesi) ortalama güç payı katsayısı 42 olarak alınmıştır.

Pülverizatörle herbisit uygulaması işleminde kişisel dağılım zamanı su içme ve kişisel ihtiyaç zamanlarından oluşmaktadır. Nesnel dağılım zamanı kapsamında ise pülverizatöre yakıt ve yağ hazırlama ve koyma zamanı ile pülverizatöre ilaç hazırlama ve koyma zamanı dikkate alınmıştır (Tablo 9). Sigara içme zamanı, iş yeri güvenliğ̣i ile iş güvenliği nedeniyle kişisel dağı̆lım zamanı içinde dikkate alınmamıştır. Çalışma amacına uygun olmayan telefon ve/veya arkadaşla görüşme zamanı ile çay içme zamanı dinlenme zamanı kapsamında değerlendirilmiş olup kișisel dağılım zamanı içinde dikkate alınmamıştır. Pülverizatörle herbisit uygulaması işleminin hazırlık zamanı bulunmamaktadır.

Bu bilgiler ışığında pülverizatörle herbisit uygula- ması işleminin birim zamanı $51,05 \mathrm{dk}$./da $(=48,33$ $\mathrm{dk} . / \mathrm{da}+[48,33 \mathrm{dk} . / \mathrm{da} \times(5,63 / 100)])$ olarak hesaplanmıştır. $\mathrm{Bu}$ aşamada makine çalışma zamanı yanında insan çalışma zamanı da hesaplanabilir. Bunun için insan çalışma zamanına dinlenme payını da eklemek gerekir. Buna göre insan çalışma birim zaman1 $69,74 \mathrm{dk} . / \mathrm{da}(=48,33 \mathrm{dk}$./da $+[48,33$ dk./da x (7,30/100)] + [48,33 dk./da x (37/100)]) olmaktadır.

\subsubsection{Solarizasyon birim zaman analizi}

Solarizasyon işleminde 1 da alanda solarizasyon için gereken insan çalışma zamanı; (i) faaliyet zamanı, (ii) dinlenme zamanı payı (\%), (iii) dağılım zamanı payı (\%) ve (iv) hazırlık zamanı toplamından oluşmaktadır. Faaliyet zamanı, ana faaliyet zamanı ile yan faaliyet zamanı toplamından oluştuğundan ana faaliyet zamanını belirlemek için $100 \mathrm{~m}^{2}$ büyüklüğündeki ekim yastı̆̆ 1 toprak doygunluğuna kadar sulanmış, ardından 6 işçi ile ekim yastığ 1 polietilen örtü (PVC) ile kaplanmış, polietilen torba kenarları toprak hava almayacak şekilde sıkıca kapatılmış ve bu işlemler için kronometreyle zaman ölçümü yapılarak ana faaliyet zamanı elde edilmiş̧ir. Buna göre 1 da alanın solarizasyon uygulaması ana faaliyet zamanı 353 dakika olarak belirlenmiştir. Solarizasyon işleminin yan faaliyet zamanı bulunmadığından faaliyet zamanı ana faaliyet zamanına eşittir.

Solarizasyon işlemi kapsamında dikkate alınan dinlenme zamanı payı Tablo 7'de gösterilmiştir. PVC örtünün ortalama ağırlığ $20 \mathrm{~kg}$ (44 libre) olarak alınmıştır. Bir işçi başına düşen örtü ağırlığının, kullanılan el aletleri ile birlikte $5 \mathrm{~kg}$ olduğu varsayılarak orta yeğinlikte ortalama güç payı katsayısı 6 olarak alınmıştır.

Dağılım zamanı, kişisel ve nesnel dağılım zamanı olarak iki grupta değerlendirilmektedir. Ancak solarizasyon işleminde nesnel dağılım zamanı bulunmamaktadır. Kişisel dağılım zamanı ise su içme ve kişisel ihtiyaç zamanlarından oluşmaktadır (Tablo 10). Sigara içme zamanı, iş yeri güvenliği ile iş güvenliği nedeniyle kişisel dağılım zamanı içinde dikkate alınmamıştır. Çalışma amacına uygun olmayan telefon ve/veya arkadaşla görüşme zamanı ile çay içme zamanı dinlenme zamanı kapsamında değerlendirilmiş olup kişisel dağılım zamanı içinde dikkate alınmamıştır. Solarizasyon işleminin hazırlık zamanı bulunmamaktadır. Tüm bu bilgiler 1şı̆̆ında solarizasyon işleminde birim zaman 422,79 dk./da. $(=353 \mathrm{dk} . / \mathrm{da}+[353 \mathrm{dk} . / \mathrm{da}$ x (18/100)]+[353 dk./da x (1,77/100)]) olarak hesap edilmiştir. 
Tablo 9. Pülverizatörle herbisit uygulaması işleminde dağ 1 lım zamanı

Table 9. Distribution time for herbicide application by pulverization

\begin{tabular}{lcccc}
\hline & Dağılım zamanı bileşenleri & Sıklık (adet) & Ort. zaman & Toplam zaman \\
\hline Kişisel dağılım & Su içme zamanı & 5 & $0,5 \mathrm{dk}$. & $2,50 \mathrm{dk}$. \\
zamanı & Kişisel ihtiyaç & 3 & $2,0 \mathrm{dk}$. & $6,00 \mathrm{dk}$. \\
Kişisel dağılım zamanının günlük çalışma zamanı (480 dk.) içindeki \% payı & & $\% 1,77$ \\
\hline Nesnel dağılım & Pülverizatöre yakıt ve yağ hazırlayıp koyma & 2 & $1,0 \mathrm{dk}$. & $2,00 \mathrm{dk}$. \\
zamanı & Pülverizatöre ilaç hazırlama ve koyma & 5 & $5,0 \mathrm{dk}$. & $25,00 \mathrm{dk}$. \\
Nesnel dağılım zamanının günlük çalışma zamanı (480 dk.) içindeki \% payı & & $\% 5,63$ \\
\hline \multicolumn{2}{l}{ Toplam dağılım zamanının günlük çalışma zamanı (480 dk.) içindeki \% payı } & & $\% 7,30$ \\
\hline
\end{tabular}

Tablo 10. Solarizasyon işleminde dağ 1 lım zamanı Table 10. Distribution time for solarization

\begin{tabular}{lccc}
\hline \multicolumn{1}{c}{ Dağılım zamanı bileşenleri } & Sıklık (adet) & Ort. zaman & Toplam zaman \\
\hline Su içme zamanı & 5 & $0,5 \mathrm{dk}$. & $2,50 \mathrm{dk}$. \\
Kişisel ihtiyaç zamanı & 3 & $2,0 \mathrm{dk}$. & $6,00 \mathrm{dk}$. \\
Dağılım zamanı toplamı & & & $8,50 \mathrm{dk}$. \\
Dağılım zamanının günlük çalışma zamanı (480 dk.) içindeki \% payı & $\% 1,77$ \\
\hline
\end{tabular}

\subsubsection{Birim maliyetler}

Elle ot alma, herbisitlerle ot mücadelesi ve solarizasyon işlemlerinin maliyetlerinde kullanılan aletlere ve iş gücüne ilişkin değerlendirmeler ve birim maliyetler Tablo 11'de sunulmaktadır. Hesaplamalarda masraflar saat başına hesaplanmış, dakika cinsinden belirlenmiş olan standart zamanlar 60'a bölünerek saate çevrilmiş ve birim maliyetler hesaplanmıştır.

Elle ot alma işleminde yılda iki adet kesim bıçağının eskitileceği ayrıca yılda iki takım diğer alet ve ekipmanların (koruyucu malzeme, kask, eldiven, dizlik vb.) kullanılacağı varsayılmıştır. İşçilik ücreti hesaplamalarında Anonim (2017) rayiç fiyatları kullanılmıștır. İşçi vasfı olarak bahçıvan ve fidan ustası ile pülverizatör operatörü alınmış, diğer malzeme ve ekipman fiyatlarında ise 2017 yılı rayiçleri dikkate alınmıştır. Pülverizatörün kullanım yoğunluğuna bağlı olarak saatte tükettiği ortalama $1,5 \mathrm{l} /$ saat benzin; $0,075 \mathrm{l} /$ saat yağ ve 0,312 1/saat kimyasal ilaç miktarları hesaplamalarda kullanılmıştır. Amortisman hesaplamalarında pülverizatör ve su dinamosunun ömrü 10 yıl alınmıştır. Bakım ve onarım giderleri için pülverizatör ve su dinamosunun yılda bir defa yapılacak bakımı dikkate alınmıştır.

Elde edilen sonuçlara göre (Tablo 11) birim maliyetler elle ot alma işleminde Eğirdir Orman Fidanlığ 1 için 1.145,866 TL/da ve Antalya Orman Fidanlığı için 1.089,195 TL/da olarak hesaplanmış- tır. Pülverizatör kullanılarak uygulanan kimyasal ot mücadelesi işlemi için 104,134 TL/da ve solarizasyon işlemi için 1.912,165 TL/da hesaplanmıştır. Eğirdir ve Antalya Orman Fidanlığının her ikisi için de yılda ortalama 7 defa elle ot alımı gerçekleştirilmektedir. Bu nedenle bu fidanlıkların yıllık elle ot alma maliyetlerini bulabilmek için hesaplanan birim zaman maliyeti 7 ile çarpılmıştır. Buna göre elle ot alma yıllık maliyeti Eğirdir Orman Fidanlığında 8.021,062 TL/da iken Antalya Orman Fidanlığında 7.624,365 TL/da olarak belirlenmiştir.

Ayrıca çalışmada yapılan herbisit uygulama sayısı doğrultusunda birim maliyet analizi yapılmıştır. Buna göre herbisit uygulaması tek bir dönemde yapıldığından, uygulamadan belli bir süre sonra yastıklarda elle ot alma işlemine devam etmiştir. Dolayısıyla herbisit uygulanan yastıklardaki yıllık maliyeti hesaplarken yapılan bu elle ot alma işleminin maliyetlerinin de eklenmesi gerekmektedir. Her iki fidanlıkta yapılan gözlemlerde herbisit uygulamalarının yaklaşık iki ot alma süresi kadar yabancı otları yastıklardan uzak tuttuğu, bundan sonraki süreçte elle ot almanın gerekli olduğu görülmüştür. Dolayısıyla kimyasal mücadelenin y1llık maliyetini hesaplarken 5 elle ot alma işlemi maliyeti de herbisit maliyetine eklenmiştir. Buna göre herbisitle yapılan mücadelenin yıllık maliyeti Eğirdir Orman Fidanlığında 5.833,464 TL/da iken Antalya Orman Fidanlığında 5.550,109 TL/da olarak hesaplanmıştır. 
Tablo 11. Farklı ișlemler için birim maliyetler (Hesaplamalar 2017 yılı rayiç fiyatlarına göre yapılmıștır) Table 11. Unit costs for different applications (Calculations were done according to 2017 current prices)

\begin{tabular}{|c|c|c|}
\hline Maliyetin konusu & Açıklama & Birim maliyet (TL/da.) \\
\hline \multicolumn{3}{|c|}{ Elle ot alma işlemi için (Eğirdir Orman Fidanlığ } \\
\hline \multicolumn{3}{|l|}{ Direkt malzeme giderleri } \\
\hline Biçak & {$[(2 \operatorname{adet} \times 12 \mathrm{TL}) / 960 \mathrm{sa}]=0,.025 \mathrm{TL} / \mathrm{sa}$. } & $3577,29 \mathrm{dk} . / \mathrm{da} . \mathrm{x}(0,025 / 60)=1,491 \mathrm{TL} / \mathrm{da}$. \\
\hline Koruyucu malzeme & {$[(2$ tak1m $\times 45 \mathrm{TL}) / 960 \mathrm{sa}]=0,.094 \mathrm{TL} / \mathrm{saat}$} & $3577,29 \mathrm{dk} . / \mathrm{da} . \times(0,094 / 60)=5,604 \mathrm{TL} / \mathrm{da}$ \\
\hline \multicolumn{3}{|c|}{ Ücret ve maaş giderler } \\
\hline İşçilik ücreti & 9,55 TL/sa. x 2 işçi=19,10 TL/sa. & $3577,29 \mathrm{dk} . / \mathrm{da} . \mathrm{x}(19,10 / 60)=1138,771 \mathrm{TL} / \mathrm{da}$ \\
\hline & Toplam & $1145,866 \mathrm{TL} / \mathrm{da}$. \\
\hline
\end{tabular}

Elle ot alma işlemi için (Antalya Orman Fidanlığı)

Direkt malzeme giderleri

Koruyucu malzeme $\quad[(2$ takım x $45 \mathrm{TL}) / 960 \mathrm{sa}]=0,.094 \mathrm{TL} / \mathrm{sa} . \quad 3404,80 \mathrm{dk} . / \mathrm{da} \mathrm{x}(0,094 / 60)=5,334 \mathrm{TL} / \mathrm{da}$

Ücret ve maaş giderleri

İşçilik ücreti $\quad 9,55 \mathrm{TL} / \mathrm{saat}$ x 2 işçi= 19,10 TL/sa.

$3404,80 \mathrm{dk} . / \mathrm{da} \times(19,10 / 60)=1083,861 \mathrm{TL} /$ da.

Toplam 1089,195 TL/da.

Direkt malzeme giderleri

\begin{tabular}{|c|c|c|}
\hline Yakit ve yağ & $\begin{array}{l}(1,5 \mathrm{lt} / \mathrm{saat} \text { benzin x } 5,15 \mathrm{TL} / \mathrm{l})+(0,075 \mathrm{l} / \mathrm{sa} . \\
\text { yağ x } 15 \mathrm{TL} / \mathrm{l})=8,850 \mathrm{TL} / \mathrm{sa} .\end{array}$ & $51,05 \mathrm{dk} . / \mathrm{da} . \times(8,850 / 60)=7,530 \mathrm{TL} / \mathrm{da}$ \\
\hline Kimyasal ilaç & $0,312 \mathrm{lt} / \mathrm{sa}$. ilaç x $145 \mathrm{TL} / \mathrm{l})=45,240 \mathrm{TL} / \mathrm{sa}$. & $51,05 \mathrm{dk} . / \mathrm{da} \times(45,240 / 60)=38,492 \mathrm{TL} / \mathrm{da}$. \\
\hline $\begin{array}{l}\text { Koruyucu malzeme } \\
\text { Ücret ve maaş giderleri }\end{array}$ & {$[(1 \mathrm{tak} 1 \mathrm{~m} \times 45 \mathrm{TL}) / 8 \mathrm{sa}]=5,.625 \mathrm{TL} / \mathrm{sa}$.} & $51,05 \mathrm{dk} . / \mathrm{da} \times(5,625 / 60)=4,786 \mathrm{TL} / \mathrm{da}$. \\
\hline İşçilik ücreti & 9,55 TL/sa. x 1 işçi=9,550 TL/sa. & $51,05 \mathrm{dk} . / \mathrm{da} \times(9,550 / 60)=8,125 \mathrm{TL} / \mathrm{da}$ \\
\hline
\end{tabular}

Saatlik makine satın alma maliyeti

Pülverizatör $\quad[(1$ adet x $2250 \mathrm{TL}) /(10 \mathrm{y} 1 \mathrm{l}$ x $8 \mathrm{sa})]=28,.125 \quad 51,05 \mathrm{dk} . / \mathrm{da} \times(28,125 / 60)=23,930 \mathrm{TL} / \mathrm{da}$.

Bakım ve onarım giderleri

Pülverizatör bakım ve $[(1 \mathrm{defa} \times 200 \mathrm{TL}) / 8 \mathrm{sa}]=25,.000 \mathrm{TL} / \mathrm{sa} . \quad 51,05 \mathrm{dk} . / \mathrm{da} . \times(25,000 / 60)=21,271 \mathrm{TL} / \mathrm{da}$. onarim1

Toplam 104,134 TL/da.

Direkt malzeme giderleri

Polietilen örtü $\quad 200 \mathrm{~m}^{2}$ örtü/sa. x $\left.1 \mathrm{TL} / \mathrm{m}^{2}\right)=200 \mathrm{TL} / \mathrm{sa} . \quad 422,79 \mathrm{dk} . / \mathrm{da} \times(200 / 60)=1409,300 \mathrm{TL} / \mathrm{da}$.

Koruyucu malzeme $\quad[(6$ tak1m x $45 \mathrm{TL}) / 48$ saat $]=5,625 \mathrm{TL} / \mathrm{sa} . \quad 422,79 \mathrm{dk} . / \mathrm{da} \times(5,625 / 60)=39,637 \mathrm{TL} / \mathrm{da}$.

Ücret ve maaş giderleri

İşçilik ücreti $\quad 9,55 \mathrm{TL} / \mathrm{saat}$ x 6 işçi= 57,300 TL/sa. $\quad 422,79 \mathrm{dk}$. $/ \mathrm{da}$. x $(57,300 / 60)=403,764 \mathrm{TL} / \mathrm{da}$.

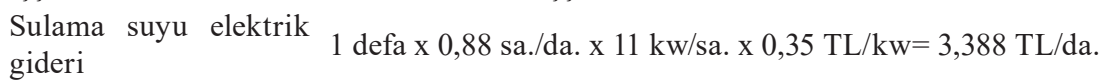

gideri

Saatlik makine satın alma maliyeti

Su dinamosu

$[(1$ adet $\times 2320 \mathrm{TL}) /(10 \mathrm{y} 11 \times 48 \mathrm{sa})]=4,$. $\mathrm{TL} / \mathrm{sa}$.

$422,79 \mathrm{dk} . / \mathrm{da} . \mathrm{x}(4,833 / 60)=34,056 \mathrm{TL} / \mathrm{da}$.

Bakım ve onarım giderleri

Su dinamosu bakım ve onarım 1

$[(1$ defa $\times 150 \mathrm{TL}) / 48 \mathrm{saat}]=3,125 \mathrm{TL} / \mathrm{sa} . \quad 422,79 \mathrm{dk} . / \mathrm{da} \times(3,125 / 60)=22,020 \mathrm{TL} / \mathrm{da}$.

Üretim sezonu başında bir kez uygulanan solarizasyon uygulaması sonrasında da elle ot alma işlemi yapılmıştır. Antalya Orman Fidanlığında ise solarizasyon uygulaması yaklaşık iki ot alma süresi kadar yabancı otları yastıklardan uzak tutmuştur. Bu sebeple Antalya Orman Fidanlığında mücadelenin y1llık maliyetini hesaplarken 5 elle ot alma işlem maliyeti de solarizasyon maliyetine eklen- miştir. Buna göre solarizasyon uygulamasının yıllık maliyeti 7.641,495 TL/da olarak hesaplanmıştır.

\section{Tartışma ve Sonuç}

Fidanlıklarda yabancı otlarla mücadelede herbisitlerin mekanik mücadeleye alternatif olarak kullanılabileceği, bu noktada herbisitlerin türünün, kullanım zamanının ve uygulama şeklinin önemli 
olduğu konuyla ilgili kaynaklarda geniş bir şekilde yer almaktadır (Boydak ve Çalışkan, 2014; Ürgenç, 1998). Bununla birlikte herbisitlerin zehirli maddeler içermesinden dolayı kullanımlarında dikkatli olunması gerektiği, doğru dozda uygun herbisitlerin kullanılmasının önemli olduğu ve özellikle doğal alanlarda çevreye karşı zararlı etkilerinden dolayı zorunlu olmadıkça kullanılmamaları gerektiği bildirilmektedir (Boydak ve Çalışkan, 2014). $\mathrm{Bu}$ kapsamda gerçekleştirilen çalışmada, Antalya Orman Fidanlığındaki herbisit uygulamasının yabancı otları etkilediği, elle ot alma işlemine oranla daha ekonomik olduğu ancak bu uygulamanın fidan sayısı ve gelişimi üzerinde olumsuz etkiler yaptığı görülmüştür. Bu nedenle Antalya Orman Fidanlığı için herhangi bir herbisit önerisinde bulunulamamaktadır.

Solarizasyon uygulaması ise yabanc1 otların örtme derecesini ortalama $\% 78,67$ oranında etkileyebilmiştir. Bu oran yabancı otlara etki bakımından yüksek bir değer olmasa da, solarizasyon uygulaması yapılan yastıklardan elde edilen fidan sayısı 395 adet fidan/m ile en yüksek değere sahip olmuştur. Fidan sayısındaki bu durum kızılçam fidan üretim alanları için önerilen fidan sayısından da yüksektir. Nitekim Gültekin (2014) yedi sıra olarak hazırlanan kızılçam ekim yastıklarındaki fidan sayısının 250-300 olması gerektiğini bildirmektedir. Ayrıca fidanların boy ve kök boğazı ölçümlerinde solarizasyon uygulanan sahalardaki fidanlar, kontrole göre çok az daha kısa boylu ve daha kalın kök boğazı çapına sahiptir. Fidan kalitesi açısından fidan boyu ve kök boğazı çapının önemi, yapılan pek çok araştırmada vurgulanmış (Eler ve ark., 1990; Dirik, 1993; Semerci, 2002; Coşgun ve ark., 2008) ve bir fidanın arazideki yaşama yüzdesinin artmas1 için düşük bir gövde/kök oranına sahip olması gerektiği bildirilmiştir (Çalışkan ve Boydak, 2015, 2017; Öztürk ve Deligöz, 2018). Bu durum dikkate alındığında solarizasyon uygulamasının Antalya Orman Fidanlığı için önerilebilir olduğu görülmektedir. Ancak çalışma kapsamında solarizasyon uygulamasının, maliyeti en yüksek olan uygulama olduğu tespit edilmiştir. $\mathrm{Bu}$ ise fidanlık çalışmalarındaki uygulanabilirliğini kısıtlayıcı bir faktör olarak ortaya çıkmaktadır. Ancak fidan maliyetini etkileyen unsurlardan biri olan işçi gücü sorununun son yıllarda Türkiye İş Kurumu (İŞKUR) tarafından uygulanan "Toplum Yararına Çalışma Programı" kapsamında orman fidanlıkları için de azaldığ 1 bilinmektedir. Bu nedenle maliyetlerin düşürülebileceği esas alınarak solarizasyonun Antalya Orman Fidanlığında kullanımının faydalı olacağı sonucuna varılmıştır. Ancak sıcaklık etkisiyle bitki çoğalma materyallerinin (tohum, rizom vb.) yok edilmesinde kullanılan solarizasyon uygu- lama süresinin uygulamanın başarısını etkileyen temel unsurlardan biri olduğu (Asav ve Kadıoğlu, 2009; Arslan, 2011) ve bu sebeple özellikle iklim özellikleri ve güneşli gün sayısı dikkate alındığında Antalya için solarizasyon uygulama yönteminde uygulama zamanının ve ayrıca solarizasyon gün sayısının önemli olduğu göz ardı edilmemelidir.

Eğirdir Orman Fidanlığında da herbisit uygulamaları yabancı otlar üzerinde etkili olmuş ve bu uygulamanın maliyetleri önemli ölçüde düşürdüğü görülmüştür. Ancak bu uygulamanın fidan sayısı ve gelişimi açısından durumu değerlendirildiğinde sadece ekim sonrası Linuron uygulanan yastıklarda yeterli miktarda (sedir ekim yastıklarında yaklaşık olarak 250-350 fidan yeterli olarak kabul edildiğinden - Gültekin, 2014) fidan elde edildiği, ancak bu fidanların da kontrol parsellerine oranla çok daha düşük boy ve çap gelişimlerine sahip oldukları görülmüştür. Bu nedenlerle Eğirdir Orman Fidanlığındaki Toros sediri fidan üretim alanları için herbisit uygulamasının şu aşamada önerilebilir nitelikte olmadığı anlaşılmıştır.

Görüldüğü üzere Antalya ve Eğirdir Orman Fidanlıklarında kullanılan herbisitler her ne kadar yabanc1 otları kontrol etmiş olsa da fidan gelişimlerinde fitotoksiteye neden olduğundan ilgili herbisitlerin kızılçam ve sedir fidan üretim alanlarında kullanı$\mathrm{m}$ önerilebilir nitelikte değildir. Bu durumun temel nedeni kullanılan herbisitlerin ilgili fidan türlerine ruhsatlı olmamasıdır. Ancak maliyet analizleri dikkate alındığında herbisit kullanımına ait sonuçlar fidan üretim alanlarında mevcut mücadele yöntemlerine göre (mekanik, kültürel) daha ekonomiktir. Bu sonuçlar fidan üretiminde türlere göre başarılı herbisitlerin belirlenmesi durumunda, ruhsatlı herbisit kullanımının ekonomik bir katkı sağlayabileceğini ortaya koymaktadır. Ancak Türkiye'de fidanlıklarda herbisit kullanımına yönelik yapılan diğer araştırmalarda da (Ata, 1978; Tolay ve ark., 1984; Gökdemir, 1998; Coşgun ve ark., 2002) vurgulandığ1 gibi herbisitlerin fidan sayıları ve gelişimi üzerinde ciddi etkileri olabilmektedir. Ayrıca fidanlıklarda herbisit kullanım alet ve ekipmanları konusunda da çalışmalar gereklidir. Örneğin Boza ve ark. (2017) tarafından geliştirilen ve umut verici sonuçlar içeren "Çekilebilir Tip Yastık İlaçlama Ekipmanı” gibi tasarımlar fidanlıklarda herbisit uygulamalarının daha uygun şekillerde yapılmasına olanak sağlayabileceği dikkate alınmalıdır.

Fidanlık çalışmalarında en önemli çıktı en yüksek sayıda ve kalitede fidan elde etmektir. Bu nedenle fidanlıklarda yapılacak her türlü çalışmanın bu amaca hizmet etmesi gerekmektedir. İlgili amaca olumsuz etki edecek uygulamalardan kaçınılma1ıdır. Özellikle Türkiye için en hızlı gelişen iğne 
yapraklı doğal türler arasında yer alan ve ayrıca klasik ve endüstriyel ağaçlandırmada Türkiye'de \%40 ağaçlandırma oranı ile önde gelen türlerden biri olan kızılçamın (Boydak ve ark., 2006; Öztürk ve Deligöz, 2018) önemi göz önüne alındığında yapılacak ağaçlandırma çalışmaları için kaliteli fidan temininin önemi ortaya çıkmaktadır.

Kaliteli fidan temininde pek çok unsur içerisinde yer alan yabanc1 ot mücadelesinde fidan kalitesini etkilemeyecek mücadele yöntemi/yöntemleri uygulamaya daha bilinçli bir şekilde aktarılmalidır. Bu nedenle öncelikle mücadelede entegre mücadele sistemi dikkate alınmalıdır. Nitekim tek bir mücadele yöntemi ile fidanlıklarda yabancı otların kontrolü yeterli olmayacaktır. Kimyasal mücadele için ise bu çalışmanın örnek olarak değerlendirilebilecek verilerinin de gösterdiği gibi ruhsatsız preparatlar farklı dönemlerde kullanılsa dahi hedef bitkilerde yüksek fitotoksite etkilerine sahip olacaktır. Herbisitler maliyetleri büyük oranda düşürdüğünden orman fidanlıklarında kullanımının daha bilinçli yapılabilmesi için fidan türüne göre ruhsatlandırılmış herbisitlerin kullanımına yönelik çalışmalar ele alınmalıdır. Ayrıca orman fidanlıklarında yabancı ot standart ilaç deneme metodu oluşturulması faydalı olacaktır. Son olarak fidanlıklarda yabancı otla mücadele programının fidanlık tesisi başlangıcından itibaren uygulamaya başlanmasının yabancı ot kontrolünün en iyi seviyede yapılmasına olanak sağlayacağı dikkate alınmalıdır.

\section{Teșekkür}

Bu çalışma Orman Genel Müdürlüğünce (OGM) desteklenip Batı Akdeniz Ormancılık Araştırma Enstitüsü tarafından yürütülen "Fidanlıklarda yabancı otlarla mücadele yöntemlerinin belirlenmesi ve kullanılan yöntemlerin fidanlık maliyetlerine katkılarının araştırılması (Eğirdir ve Antalya Orman Fidanlık Müdürlükleri Örneği)" başlıklı ve 19.1211/2014-2017 numaralı proje kapsamında gerçekleştirilmiştir. Çalışmanın istatistik analizlerinin gerçekleştirilmesi aşamasındaki yardımlarından dolayı Karabük Üniversitesi Öğr. Üyesi Dr. Mural ALAN'a ve arazideki yardımlarından dolayı Eğirdir ve Antalya Orman Fidanlık Müdürlüğü çalışanlarına teşekkür ederiz.

\section{Kaynaklar}

Anonim, 1994. Weed management for developing countries. Food and Agriculture Organization of United Nations (FAO). Plant Production and Protection Paper 120, 384 s., Italy.

Anonim, 2015. Türkiye orman varlığı. Orman Genel Müdürlüğü yayını, 32 s. Ankara.
Anonim, 2017. Çevre ve Şehircilik Bakanlığı, 2017 Yılı Yapı İşleri İnşaat Birim Fiyatlarına Esas İşçilik-Araç ve Gereç Rayiç Listesi.

Asav, Ü., Kadıŏlu, İ., 2009. Solarizasyon ve solarizasyonun tavuk gübresi ile kombinasyonunun bazı yabanc1 otlar ile buğdayın verim ve verim unsurlarına etkisi. GOÜ. Ziraat Fakültesi Dergisi, 26(2), 19-25

Ata, C., 1978. Fidanlıklarda otla mücadele, KTÜ Orman Fakültesi Dergisi 1(1): 40-49.

Arslan, Z.F., 2011. Domates üretiminde sorun olan yabancı otlara karşı organik tarıma uygun bazı mücadele yöntemlerinin araştırılması. Çukurova Üniversitesi, Fen Bilimleri Enstitüsü Doktora Tezi, 267 s., Adana.

Boydak, M., Dirik, H., Çalıkoğlu, M. 2006. Kızılçamın (Pinus brutia Ten.) biyolojisi ve silvikültürü. OGEMVak yayını, Ankara.

Boydak ve Çalışkan, 2014. Ağaçlandırma, OGEM-VAK yayın1, Ankara.

Boza, Z. ve ark. 2017. Orman fidanlıkları için çekilebilir tip yastık ilaçlama ekipmanının tasarımı ve prototipinin yapılması. EGE Ormancılık Araştırma Enstitüsü 115.2112/2012-2016 no.lu Araştırma Projesi Sonuç Raporu.

Çalıșkan, S., Boydak, M. 2015. Afforestation in arid and semi-arid regions.General Directorate of Combation Desertification and Erosion. Ankara.

Çalışkan, S., Boydak, M. 2017. Afforestation of arid and semiarid ecosystems in Turkey. Turkish Journal of Agriculture and Forestry, 41:317-330.

Cobb, A., Reade, J.P.H., 2010. Herbicides and plant physiology. Wiley-Blackwell, NewPort, UK

Coşgun, U., Erdem, M., Topak, R., Terzi, M., 2002. Bolu Orman Fidanlığında tarımda kullanılan herbisitlerin kullanılmasının ot mücadelesine fidan yaşama kabiliyetine ve fidanlık ekonomisine katkılarının incelenmesi, Batı Karadeniz Ormancılık Araştırma Enstitüsü, Teknik Bülten No: 8, Bolu

Coşgun, S., Şahin, M., Özkurt N., Parlak, S., 2008. K1zılçam (Pinus brutia Ten.) fidanlarında kalite sınıflarının belirlenmesi, Batı Akdeniz Ormancılık Araştırma Müdürlüğ̈̈, Teknik Bülten No: 29, Antalya

Delen, N., Durmuşoğlu, E., Güncan, A., Güngör, N., Turgut, C., Burçak, A. 2005. Türkiye'de pestisit kullanımı, kalıntı ve organizmalarda duyarlılık azalışı sorunları. Türkiye Ziraat Mühendisliği VI. Teknik Kongresi, Ankara, 3-7 Ocak 2005, s. 629-648

Dirik, H., 1993. Kızılçam (Pinus brutia Ten.)'da bazı önemli fidan karakteristikleri ile dikim başarısı arasındaki ilişkiler, İ.Ü. Orman Fakültesi Dergisi, A:43(2):51-57

Dişbudak, K., 2008. Avrupa Birliği'nde Tarım-Çevre ilişkisi ve Türkiye'nin uyumu. T.C. Tarım ve Köyişleri 
Bakanlığı Dış İlişkiler ve Avrupa Birliği Koordinasyon Dairesi Başkanlığı. AB Uzmanlık Tezi 79 s.

Eler, Ü., Keskin, S., Örtel, E., 1990. Toros sediri (Cedrus libani A. Rich.) fidanlarında kalite sınıflarının belirlenmesi, Ormancılık Araştırma Enstitüsü, Teknik Bülten No: 240, Ankara

Erdem, M., Arslan, A., Abbak, A. [...] Gençoğlan, F., Ural, M., Özalp, A., 2017. Kayın, meşe, göknar, sarıçam, karaçam ve kızılçamın üretim işlerinde birim zaman analizi. OGM Batı Karadeniz Ormancılık Araştırma Enstitüsü Müdürlüğü, Proje Sonuç Raporu, 232s, Bolu

Eşen, D., Yıldız, O., 2000. Otsu ve odunsu diri örtü mücadelesinin meşcerelerin gençleştirilmesi ve büyümesine etkileri. Orman Mühendisleri Odası Dergisi, 37: 28-32

Eşen, D., Yıldız, O., Sargıncı, M., Güneş, N., 2005. Ormancilıkta zararlı ot ilaçlarının kullanımı ve riskleri. A.I.B.Ü. Ormancılık Dergisi, 1(2): 51-58

Gökdemir, Ş., 1998. Orman fidanlıklarında (Ordu, Hendek ve Devrek) belirlenen yabancı otlar ve kimyasal savaşımları üzerine araştırmalar. Karadeniz Teknik Üniversitesi, Fen Bilimleri Enstitüsü, Doktora Tezi, 143 s. Trabzon.

Gökdemir, Ş. 2007.Yabanc1 otlarla kimyasal mücadele ve etkileri. In: Yahyaoğlu, Z. ve Genç, M. (eds.) Fidan Standardizasyonu, Süleyman Demirel Üniversitesi Orman Fakültesi Yayını, no 75, 217-242.

Gültekin, H.C., 2014. Önemli orman ağaçlarının fidan üretim teknikleri. Kavak ve Hızlı Gelişen Orman Ağaçları Araştırma Enstitüsü, Çeşitli Yayınları Serisi No: 26, İzmit.

Güner, A., Aslan, S., Ekim, T., Vural M., Babaç, MT. (edlr.) 2012. Türkiye bitkileri listesi (Damarlı bitkiler). Nezahat Gökyiğit Botanik Bahçesi ve Flora Araştırmaları Derneği Yayını. İstanbul.

Güncan, A., Karaca, M., 2018. Yabanc1 ot mücadelesi. Selçuk Üniversitesi Basımevi. IV. Baskı s.. 186-189, Konya.

Gündüz, Ş., Kersting, U., Kahramanoğlu, İ., 2006, Turunçgil bahçelerindeki yabancı otlar ve entegre mücadele yöntemleri, Akdeniz İhracatçıları Birlikleri, Mersin.

IBM Corp. Released 2016. IBM SPSS Statistics for Win- dows, Version 24.0. Armonk, NY: IBM Corp.

Kegley, S., Hill, B., Orme, S., Choi, A., 2010. Pesticide action network pesticide database. Pesticide Action Network, North America, San Francisco, CA, (Erişim tarihi: 04/10/2018, http://www.pesticideinfo.org)

Mathers, H., 1999. Weed control in nurseries, Part II. Department of Horticulture and Crop Science, Ohio State University

Moya, M., Furukawa, G. 2000. Use of solar energy (solarization) for weed control in greenhouse soil for ornamental crops, In: Proceedings of the 53. Conference on Use of Solar Energy, New Zealand Plant Protection, p.34-37, New Zealand.

Öztürk, N., Deligöz, A., 2018. Farklı tohum bahçelerine ait kızılçam (Pinus brutia) fidanlarının bazı morfolojik, fizyolojik ve biyokimyasal özelliklerinin araştırılması. Süleyman Demirel Üniversitesi Fen Bilimleri Enstitüsü Dergisi, 22(2): 924-931

Parlak, S., 2016. Kültüre alınan Anacamptis sancta parsellerinde yabancı otlarla mücadelede kimyasal ve mekanik yöntemlerin etkinliğinin belirlenmesi. Ormancllık Araştırma Dergisi, 4: 126-133

Şanlı, A., Kaya, M., Kara, B., 2009, Nohut (Cicer arietinum L.) ta yabanc1 ot mücadele zamanlar1 ile herbisit uygulamalarının verim ve bazı verim unsurlarının etkileri, Anadolu Tartm Bilim Dergisi 24(1): 13-20

Semerci, A., 2002. Sedir (Cedrus libani A. Rich.) fidanlarına ait bazı morfolojik ve fizyolojik karakteristikler ile İç Anadolu'daki dikim başarısı arasındaki ilişkiler. İç Anadolu Ormancılık Araştırma Müdürlüğü, Teknik Bülten No: 279, Ankara

Tolay, U., Ayberk, S., Sarıbaş, M. Zoralioğlu, T. 1984. Fidanlıkta yabani otlarla mücadele. Kavak ve Hizlı Gelișen Yabancı Tür Orman Ağaçları Araștırma Enstitüsü, Araştırma Sonuç Raporu, İzmit.

Ürgenç, S. 1998. Ağaç ve süs bitkileri fidanlık ve yetiştirme tekniği, İstanbul Üniversitesi Orman Fakültesi yayınlar1, no 3994/441, İstanbul.

Yazlık, A., Tepe, I., 2017. Van ve yöresinde elma ve armut bahçelerindeki yabancı otlar ve dağılışları üzerinde araştırmalar. Türkiye Herboloji Dergisi, 4 (1): 11-20. 